Asian Pacific Journal of Reproduction

Journal homepage: www.apjr.net

\title{
Evaluation of infertile women: Mini-review
}

\author{
Mohannad Abu Faza ${ }^{1}$, Ibrahim A Abdelazim ${ }^{1,2 \bowtie}$, Hossam S Osman ${ }^{1}$, Dareen A Alsharif \\ ${ }^{I}$ Department of Obstetrics and Gynecology, Ahmadi Hospital, Kuwait \\ ${ }^{2}$ Department of Obstetrics and Gynecology, Ain Shams University, Egypt
}

\section{ARTICLE INFO}

\section{Article history:}

Received 10 November 2016

Revision 12 December 2016

Accepted 20 December 2016

Available online 1 January 2017

\section{Keywords:}

Infertile

Women

Mini-review

\begin{abstract}
Evaluation of infertility indicated for women failed to conceive after one year of unprotected intercourse and for women over 35 years failed to conceive after 6 mo of unprotected intercourse, because the fertility decline as women approach 40 years. Evaluation of infertile couple should begin with semen analysis of male partner. If the semen analysis is within normal range, evaluation then move on to female partner. Evaluation of the infertile woman should be carried in cost-effective manner to identify the causes of infertility using the least invasive methods. Methods of evaluation of infertile women include: 1) history and physical examination; 2) evaluation of the male partner; 3) documentation of ovulation; 4) evaluation of the ovarian reserve; 5) evaluation of cervical causes of infertility; 6) evaluation of uterine causes of infertility; 7) documentation of the tubal patency; and 8) exclusion of peritoneal causes of infertility. Evaluation of infertile couple should include evaluation of both partners. Semen analysis for the male partner, followed by documentation of ovulation and evaluation of genital tract patency. PCT is not used as routine evaluation of infertile women. Laparoscopy is not used as routine evaluation of infertile women unless there is suspected peritoneal factors of infertility or endometriosis or tubal occlusion. Ovarian reserve should only be done for infertile women with diminished response to external gonadotropins (not routine).
\end{abstract}

\section{Introduction}

Evaluation of infertility indicated for women failed to conceive after one year of unprotected intercourse and for women over 35 years failed to conceive after 6 mo of unprotected intercourse, because the fertility decline as women approach 40 years[1,2].

Evaluation of infertile couple should begin with semen analysis of male partner. If the semen analysis of the male partner is within normal range, evaluation of the female partner should start.

The evaluation of the infertile woman should be carried in costeffective manner to identify the causes of infertility using the least invasive methods.

Corresponding author: Ibrahim A Abdelazim, Obstetrics and Gynecology, Ain Shams University, Egypt and Consultant at Ahmadi Hospital, Kuwait Oil Company (KOC), Kuwait.

Tel: (+965)-66551300.

E-mail: dr.ibrahimanwar@gmail.com

ORCID: http://orcid.org/0000-0002-7241-2835

\section{Methods of evaluation of infertile women}

Methods of evaluation of infertile women include; 1) history and physical examination; 2) evaluation of the male partner; 3 ) documentation of ovulation; 4) evaluation of the ovarian reserve; 5) evaluation of cervical causes of infertility; 6) evaluation of uterine causes of infertility; 7) documentation of the tubal patency; and 8) exclusion of peritoneal causes of infertility[1,2].

This is an open access article distributed under the terms of the Creative Commons Attribution-Non Commercial-Share Alike 3.0 License, which allows others to remix, tweak and buid upon the work non-commercially, as long as the author is credited and the new creations are licensed under the identical terms.

For reprints contact: reprints@medknow.com

C2017 Asian Pacific Journal of Reproduction Produced by Wolters Kluwer- Medknow

How to cite this article: Mohannad Abu Faza, Ibrahim A Abdelazim, Hossam S Osman, Dareen A Alsharif. Evaluation of infertile women: Mini-review. Asian Pac J Reprod 2017; 6(1): 1-5. 


\subsection{Thorough history includes}

Infertility duration and previous treatment of infertility, menstrual history (menarche, length of the menstrual cycle, dysmenorrhea), obstetrics history and pregnancy outcome, history of contraception, sexual history (frequency, sexual dysfunction and/or dyspareunia), past surgical history, previous pelvic inflammatory disease or sexually transmitted disease, endocrine disorders (thyroid disease, galactorrhea, hirsutism), previous cervical cytology, drug allergy, family history of congenital malformations and/or infertility problem, smoking, use of alcohol or exposure to environmental toxins $[1,2]$

\subsection{Physical examination}

Physical examination includes blood pressure, pulse rate, body mass index (BMI), weight, thyroid and breast examinations, hair distribution, vaginal and pelvic examination (vaginal, cervical, uterine, adnexal pathology or masses and pouch of Douglas).

Subsequent evaluation of the infertile woman should be carried in cost-effective manner to identify the causes of infertility using the least invasive methods[2,3].

\subsection{Documentation of ovulation}

Ovulatory disorders identified as possible cause of infertility in $40 \%$ of infertile women[3], and commonly associated with menstrual disturbances. Commonest ovulatory disorders associated with infertility include polycystic ovarian disease (PCOD), excess weight gain or excess weight loss, vigorous exercise, thyroid problems and hyperprolactinemia. Methods for documentation of ovulation state as follow.

\subsubsection{Basal body temperature (BBT)}

In ovulatory women, the menstrual cycle is regular, which occurs every 21-35 d with constant premenstrual symptoms[4]. BBT provides a simple method for evaluation of ovulation. Ovulatory cycles associated with biphasic BBT recordings, and an-ovulatory cycles associated with monophasic BBT pattern[5]. BBT assay is not the best method for documentation of ovulation in most of women

\subsubsection{Serum progesterone assay}

Serum progesterone was considered a reliable indicator of ovulation and luteal function. Serum progesterone assay should be done $1 \mathrm{wk}$ before the beginning of the menses rather than day-21 assay. Serum progesterone more than $3 \mathrm{ng} / \mathrm{mL}$ is a reliable indicator of ovulation[6]. Serum progesterone more than $10 \mathrm{ng} / \mathrm{mL}$ is a reliable indicator of proper luteal function[7].

\subsubsection{Luteinizing Hormone (LH) assay in urine}

Commercial 'ovulation detection kits' was used to identify the LH surge occurring 1 or $2 \mathrm{~d}$ before the ovulation. Urinary LH is an accurate, easy and a reliable method to identify the best ovulation and fertility time[8,9].

\subsubsection{Endometrial biopsy and dating}

Detection of secretory endometrium, resulting from the postovulatory progesterone effect and endometrial dating to diagnose luteal phase defect was the gold standard method to diagnose ovulation and/or luteal phase defect. However, this method can't differentiate between fertile and infertile female and should considered for diagnosis of pathological endometrial lesions as endometrial neoplasia and/or chronic endometritis[10,11].

\subsubsection{Trans-vaginal ultrasound (TVS)}

Trans-vaginal ultrasound was used to detect the growth of the ovarian follicles and evidence of ovulation through, collapse of the mature follicles, loss of the follicular margins, and appearance of post-ovulatory clear fluid in the pouch of Douglas[12].

\subsubsection{Endocrine assessment}

Thyroid-stimulating hormone and prolactin levels assay indicated in infertile women, because the thyroid problems and hyperprolactinaemia are the commonest endocrine disorders associated with ovulatory dysfunction and subsequent infertility.

\subsection{Evaluation of the ovarian reserve}

Ovarian reserve describes the reproductive ability of the woman through identification of the number and quality of the oocytes are available[13]. Decreased ovarian reserve (DOR) means women whose response to ovarian stimulation reduced compared to women of the same age. Ovarian reserve can detected by cycle-day 3 Follicle Stimulating Hormone (FSH) and estradiol levels, clomiphene citrate challenge test, antral follicle count (AFC), and anti-mullerian hormone (AMH).

These above mentioned tests may provide prognostic information about women at increased risk of DOR, such as women who; 1) over age 35 ; 2) family history of premature ovarian failure; 3 ) past history of ovarian surgery or radiation; 4) unexplained infertility[13]. Ovarian reserve helps to detect the ovarian response to exogenous gonadotropins stimulation during in-vitro-fertilization (IVF) treatment[14].

Cycle-day 3 Serum FSH and estradiol: Cycle-day 2-4 FSH commonly used to measure the ovarian reserve. FSH more than 10$20 \mathrm{mIU} / \mathrm{mL}$ is associated with DOR[15]. Serum estradiol is not used 
alone for assessment of the ovarian reserve and its measurement should combined with measurement of the serum FSH[16].

Normal serum FSH with elevated estradiol more than $60 \mathrm{pg} / \mathrm{mL}$ in follicular phase associated with DOR and increased rate of IVF cycle cancellation[17,18].

Clomiphene Citrate Challenge: The clomiphene citrate challenge test means assessment of the FSH on day 3 and day 10 of the menstrual cycle after $100 \mathrm{mg}$ clomiphene citrate daily from day 5 to day 9 of the menstrual cycle. High serum FSH after clomid stimulation suggest DOR[19].

AFC: AFC assessment by TVS should done in early follicular phase. Antral follicles means detection of the follicles measuring $2-10 \mathrm{~mm}$ in diameter in the ovaries. Data are expressed as mean $\pm \mathrm{SD}$. AFC of $(5.2 \pm 2.1)$ is associated with DOR[20,21]. AFC increased in women with PCOD and decreased in women receiving combined contraceptive pills[22-25].

Serum AMH Level: AMH secreted by follicular granulosa cells, gonadotropin-independent and therefore can be measured in any day of the cycle[26-31]. AMH decreased with external use of contraceptive pills or gonadotrophic releasing hormones $(\mathrm{GnRH})$, and hypogonadotropic hypogonadism[32-35]. AMH less than $1 \mathrm{ng} /$ $\mathrm{mL}$ usually associated with DOR and poor IVF outcome[32-35]. AMH increased in women with PCOD[36-40].

\subsection{Evaluation of cervical causes of infertility}

Evaluation of the cervical causes of infertility using post-coital test (PCT) which means microscopic examination of the cervical mucus specimen taken before the ovulation for the appearance of the motile sperms is not recommended for routine assessment of infertile women, because of the subjective nature of the PCT[41,42].

\subsection{Evaluation of uterine causes of infertility}

Methods used for assessment of the uterine causes of infertility include TVS, three-dimensional ultrasound and MRI, with the purpose to diagnose uterine leiomyomas, congenital uterine anomalies and pathological ovarian lesions.

Hysterosalpingography (HSG) used in infertile women for diagnosis of uterine anomalies, endometrial polyps and sub-mucous myomas with high positive predictive value (PPV)[43].

Sonohysterography or saline infusion sonograpohy (SIS) means infusion of saline through the cervical canal during the trans-vaginal ultrasound. Sonohysterography or SIS used in infertile women for diagnosis of uterine anomalies, endometrial polyps and sub-mucous myomas with more than 90\% PPV[44-47]. Hysteroscopy is the gold standard for evaluation of the uterine cavity and for diagnosis of the intrauterine pathology[47].

\subsection{Documentation of the tubal patency}

Methods used to document tubal patency include HSG that is the standard method used for evaluation of the tubal patency. HSG can diagnose tubal occlusion, salpingitis isthmica nodosa, fimbrial phimosis or peritubal adhesions. The positive predictive value (PPV) and negative predictive value (NPV) of HSG are 38\% and $94 \%$ respectively[48,49]. SIS can also be used to document the tubal patency. Diagnostic Laparoscopy with dye test used for the diagnosis of tubal occlusion and peritubal adhesions, which is not diagnosed by HSG[50]. Chlamydia trachomatis antibodies detected in infertile women with tubal pathology with high negative value $80 \%-90 \%[51,52]$.

\subsection{Evaluation of peritoneal causes of infertility}

Peritoneal factors of infertility such as endometriosis and pelvic adhesions should be expected in women with unexpected infertility[53]. Laparoscopy is the most specific method used for the diagnosis of peritoneal factors of infertility. Laparoscopy indicated in infertile women with abnormal HSG or abnormal ultrasound findings or risk factors of peritoneal diseases and not recommended as routine evaluation of infertility women[54,55].

\section{Conclusion}

Evaluation of infertility indicated for women failed to conceive after one year of unprotected intercourse and for women over 35 years failed to conceive after 6 mo of unprotected intercourse. Evaluation of infertile couple should include evaluation of both partners. Semen analysis for the male partner is followed by documentation of ovulation and evaluation of genital tract patency. PCT was not used as a routine evaluation of infertile women. Laparoscopy was not used as a routine evaluation of infertile women unless there is suspected peritoneal factors of infertility, endometriosis or tubal occlusion. Ovarian reserve should only be done for infertile women with diminished response to external gonadotropins (not routine).

\section{Conflict of interest statement}

The authors declare that they have no conflict of interest. 


\section{References}

[1] Practice Committee of American Society for Reproductive Medicine. Definitions of infertility and recurrent pregnancy loss: A committee opinion. Fertil Steril 2013; 99(1): 63.

[2] Practice Committee of American Society for Reproductive Medicine. Diagnostic evaluation of the infertile male: A committee opinion. Fertil Steril 2015; 103(3): e18-25.

[3] Mosher WD, Pratt WF. Fecundity and infertility in the United States: Incidence and trends. Fertil Steril 1991; 56(2): 192-193.

[4] Munster K, Schmidt L, Helm P. Length and variation in the menstrual cycle-a cross-sectional study from a Danish county. Br J Obstet Gynaecol 1992; 99(5): 422-429.

[5] Luciano AA, Peluso J, Koch EI, Maier D, Kuslis S, Davison E. Temporal relationship and reliability of the clinical, hormonal, and ultrasonographic indices of ovulation in infertile women. Obstet Gynecol 1990; 75(1): 412416.

[6] Wathen NC, Perry L, Lilford RJ, Chard T. Interpretation of single progesterone measurement in diagnosis of anovulation and defective luteal phase: Observations on analysis of the normal range. $\mathrm{Br} \mathrm{Med} J$ (Clin Res Ed) 1984; 288(6410): 7-9.

[7] Jordan J, Craig K, Clifton DK, Soules MR. Luteal phase defect: The sensitivity and specificity of diagnostic methods in common clinical use. Fertil Steril 1994; 62(1): 54-62.

[8] Practice Committee of American Society for Reproductive Medicine in collaboration with Society for Reproductive Endocrinology and Infertility. Optimizing natural fertility: A committee opinion. Fertil Steril 2013; 100(3): 631-637

[9] McGovern PG, Myers ER, Silva S, Coutifaris C, Carson SA, Legro RS, et al. Absence of secretory endometrium after false-positive home urine luteinizing hormone testing. Fertil Steril 2004; 82(5): 1273-1277.

[10]Murray MJ, Meyer WR, Zaino RJ, Lessey BA, Novotny DB, Ireland $\mathrm{K}$, et al. A critical analysis of the accuracy, reproducibility, and clinical utility of histologic endometrial dating in fertile women. Fertil Steril 2004; 81(5): 1333-1343.

[11]Coutifaris C, Myers ER, Guzick DS, Diamond MP, Carson SA, Legro RS, et al. Histological dating of timed endometrial biopsy tissue is not related to fertility status. Fertil Steril 2004; 82(5): 1264-1272.

[12]de Crespigny LC, O'Herlihy C, Robinson HP. Ultrasonic observation of the mechanism of human ovulation. Am J Obstet Gynecol 1981; 139(6): 636-639.

[13]Practice Committee of the American Society for Reproductive Medicine. Testing and interpreting measures of ovarian reserve. Fertil Steril 2015; 103(3): e9-17.

[14]Broekmans FJ, Kwee J, Hendriks DJ, Mol BW, Lambalk CB. A systematic review of tests predicting ovarian reserve and IVF outcome. Hum Reprod Update 2006; 12(6): 685-718.

[15]Johnson NP, Bagrie EM, Coomarasamy A, Bhattacharya S, Shelling AN,
Jessop S, et al. Ovarian reserve tests for predicting fertility outcomes for assisted reproductive technology: The International Systematic Collaboration of Ovarian Reserve Evaluation protocol for a systematic review of ovarian reserve test accuracy. BJOG 2006; 113(12):1472-1480.

[16]Esposito MA, Coutifaris C, Barnhart KT. A moderately elevated day 3 FSH concentration has limited predictive value, especially in younger women. Hum Reprod 2002; 17(1): 118-123.

[17]Licciardi FL, Liu HC, Rosenwaks Z. Day 3 estradiol serum concentrations as prognosticators of ovarian stimulation response and pregnancy outcome in patients undergoing in vitro fertilization. Fertil Steril 1995; 64(5): 991-994.

[18]Smotrich DB, Widra EA, Gindoff PR, Levy MJ, Hall JL, Stillman RJ. Prognostic value of day 3 estradiol on in vitro fertilization outcome. Fertil Steril 1995; 64(6): 1136-1140.

[19]Hendriks DJ, Mol BW, Bancsi LF, te Velde ER, Broekmans FJ. The clomiphene citrate challenge test for the prediction of poor ovarian response and nonpregnancy in patients undergoing in vitro fertilization: A systematic review. Fertil Steril 2006; 86(4): 807-818.

[20]Aru Balmagambetova, Ibrahim A Abdelazim, Erbol Bekmukhambetov, Gulmira Zhurabekova, Amr H Yehia, Mohannad Abu Faza. Ovarian parameters and ovarian blood flow of women living in the area of environmental crisis. Eur J Obstet Gynecol Reprod Biol 2016; 200: 68-71.

[21]Aru Balmagambetova, Gulmira Zhurabekova, Ibrahim A Abdelazim, Sapargali Rakhmanov. Effect of environmental factors on ovarian reserve of women living in Aral Sea area. J Infertil Reprod Biol 2015; 3(1): 145149.

[22]Hendriks DJ, Mol BW, Bancsi LF, te Velde ER, Broekmans FJ. Antral follicle count in the prediction of poor ovarian response and pregnancy after in vitro fertilization: A meta-analysis and comparison with basal follicle-stimulating hormone level. Fertil Steril 2005; 83(2): 291-301.

[23]Rosen MP, Johnstone E, Addauan-Andersen C, Cedars MI. A lower antral follicle count is associated with infertility. Fertil Steril 2011; 95(6): 1950-1954.

[24]Leonhardt H, Hellstrom M, Gull B, Lind A, Nilsson L, Janson PO, et al. Ovarian morphology assessed by magnetic resonance imaging in women with and without polycystic ovary syndrome and associations with antimullerian hormone, free testosterone, and glucose disposal rate. Fertil Steril 2014; 101(6): 1747-1756.

[25]Bentzen JG, Forman JL, Pinborg A, Lidegaard O, Larsen EC, FriisHansen L, et al. Ovarian reserve parameters: A comparison between users and nonusers of hormonal contraception. Reprod Biomed Online 2012; 25(6): 612-619.

[26]Fanchin R, Taieb J, Lozano DH, Ducot B, Frydman R, Bouyer J. High reproducibility of serum anti-mullerian hormone measurements suggests a multistaged follicular secretion and strengthens its role in the assessment of ovarian follicular status. Hum Reprod 2005; 20(4): 923927.

[27]Tsepelidis S, Devreker F, Demeestere I, Flahaut A, Gervy C, Englert 
Y. Stable serum levels of anti-mullerian hormone during the menstrual cycle: A prospective study in normo-ovulatory women. Hum Reprod 2007; 22(7): 1837-1840.

[28]La Marca A, Stabile G, Artenisio AC, Volpe A. Serum anti-mullerian hormone throughout the human menstrual cycle. Hum Reprod 2006; 21(12): 3103-3107

[29]Hehenkamp WJ, Looman CW, Themmen AP, de Jong FH, Te Velde ER, Broekmans FJ. Anti-mullerian hormone levels in the spontaneous menstrual cycle do not show substantial fluctuation. J Clin Endocrinol Metab 2006; 91(10): 4057-4063.

[30]IA Abdelazim, MM Belal, HH Makhlouf. Anti-mullerian hormone and antral follicle count as predictors of ovarian reserve and successful IVF. Asian Pac J Reprod 2012; 1(2): 89-92.

[31]Ibrahim A Abdelazim, Khaled M Abdelrazak, Assem AM Elbiaa, Mohamed M Farghali, Amr Essam, Gulmira Zhurabekova. Ovarian function and ovarian blood supply following premenopausal abdominal hysterectomy. Prz Menopauzalny 2015; 14(4): 238-242.

[32]Dolleman M, Verschuren WM, Eijkemans MJ, Dolle ME, Jansen EH, Broekmans FJ, et al. Reproductive and lifestyle determinants of antimullerian hormone in a large population-based study. J Clin Endocrinol Metab 2013; 98(5): 2106-2115.

[33]Kallio S, Puurunen J, Ruokonen A, Vaskivuo T, Piltonen T, Tapanainen JS. Anti-mullerian hormone levels decrease in women using combined contraception independently of administration route. Fertil Steril 2013; 99(5): 1305-1310.

[34]Su HI, Maas K, Sluss PM, Chang RJ, Hall JE, Joffe H. The impact of depot GnRH agonist on AMH levels in healthy reproductive-aged women. J Clin Endocrinol Metab 2013; 98(12): e1961-1966.

[35]Chan C, Liu K. Clinical pregnancy in a woman with idiopathic hypogonadotropic hypogonadism and low AMH: Utility of ovarian reserve markers in IHH. J Assist Reprod Genet 2014; 31(10): 1317-1321.

[36]Pigny P, Merlen E, Robert Y, Cortet-Rudelli C, Decanter C, Jonard S, et al. Elevated serum level of anti-mullerian hormone in patients with polycystic ovary syndrome: Relationship to the ovarian follicle excess and to the follicular arrest. J Clin Endocrinol Metab 2003; 88(12): 5957-5962.

[37]Laven JS, Mulders AG, Visser JA, Themmen AP, DeJong FH, Fauser BC. Anti-mullerian hormone serum concentrations in normoovulatory and anovulatory women of reproductive age. J Clin Endocrinol Metab 2004; 89(1): 318-323.

[38]Muttukrishna S, McGarrigle H, Wakim R, Khadum I, Ranieri DM, Serhal P. Antral follicle count, anti-mullerian hormone and inhibin B: Predictors of ovarian response in assisted reproductive technology? BJOG 2005; 112(10): 1384-1390.

[39]Muttukrishna S, Suharjono H, McGarrigle H, Sathanandan M. Inhibin B and anti-mullerian hormone: Markers of ovarian response in IVF/ICSI patients? BJOG 2004; 111(11): 1248-1253.

[40]Silberstein T, MacLaughlin DT, Shai I, Trimarchi JR, LambertMesserlian G, Seifer DB, et al. Mullerian inhibiting substance levels at the time of HCG administration in IVF cycles predict both ovarian reserve and embryo morphology. Hum Reprod 2006 ; 21(1): 159-163.

[41]Griffith CS, Grimes DA. The validity of the postcoital test. Am J Obstet Gynecol 1995; 172(1): 1327.

[42]Oei SG, Helmerhorst FM, Bloemenkamp KW, Hollants FA, Meerpoel DE, Keirse MJ. Effectiveness of the postcoital test: Randomised controlled trial. BMJ 1998; 317(7157): 502-505

[43]Soares SR, Barbosa dos Reis MM, Camargos AF. Diagnostic accuracy of sonohysterography, transvaginal sonography, and hysterosalpingography in patients with uterine cavity diseases. Fertil Steril 2000; 73(2): 406-411.

[44]Schwarzler P, Concin H, Bosch H, Berlinger A, Wohlgenannt K, Collins WP, et al. An evaluation of sonohysterography and diagnostic hysteroscopy for the assessment of intrauterine pathology. Ultrasound Obstet Gynecol 1998; 11(5): 337-342.

[45]Salle B, Gaucherand P, de Saint Hilaire P, Rudigoz RC. Transvaginal sonohysterographic evaluation of intrauterine adhesions. J Clin Ultrasound 1999; 27(3): 131-134.

[46]Hamilton JA, Larson AJ, Lower AM, Hasnain S, Grudzinskas JG. Routine use of saline hysterosonography in 500 consecutive, unselected, infertile women. Hum Reprod 1998; 13(9): 2463-2473.

[47]Abdelazim IA, Elezz AA. Complementary roles of hysteroscopy and saline infusion hysterosonography in uterine cavity assessment before in vitro fertilization. Asian Pac J Reprod 2012; 1(1):13-16.

[48]Practice Committee of American Society for Reproductive Medicine. Committee opinion: Role of tubal reconstructive surgery in the era of assisted reproductive technology. Fertil Steril 2015; 103(6): e44-50.

[49]Coppus SF, Opmeer BC, Logan S, van der Veen F, Bhattacharya S, Mol BW. The predictive value of medical history taking and Chlamydia IgG ELISA antibody testing (CAT) in the selection of subfertile women for diagnostic laparoscopy: A clinical prediction model approach. Hum Reprod 2007; 22(5): 1353-1358.

[50]Valle RF. Tubal cannulation. Obstet Gynecol Clin North Am 1995; 22: 519 540

[51]den Hartog JE, Morre SA, Land JA. Chlamydia trachomatis-associated tubal factor subfertility: Immunogenetic aspects and serological screening. Hum Reprod Update 2006; 12(6): 719-730.

[52]Ubaldi F, Wisanto A, Camus M, Tournaye H, Clasen K, Devroey P. The role of transvaginal ultrasonography in the detection of pelvic pathologies in the infertility workup. Hum Reprod 1998; 13(2): 330-333.

[53]Marcoux S, Maheux R, Berube S. Laparoscopic surgery in infertile women with minimal or mild endometriosis. Canadian Collaborative Group on Endometriosis. N Engl J Med 1997; 337: 217-222.

[54]Jacobson TZ, Duffy JM, Barlow D, Farquhar C, Koninckx PR, Olive D. Laparoscopic surgery for subfertility associated with endometriosis Cochrane Database Syst Rev 2010; 20(1): CD001398.

[55]Evers JL, Land JA, Mol BW. Evidence-based medicine for diagnostic questions. Semin Reprod Med 2003; 21(1): 9-15. 